\title{
László Ervin
}

\section{A létFontosságú FELADATOK}

\author{
DOI 10.35402/kek.2021.2.18
}

Az elöttünk álló út nem lesz könnyű. Ismert tény, hogy a globális dimenziók átalakulása már elkezdődött, a kimenetelét azonban még nem látjuk elöre. Annyit már tudunk, hogy kihívást fog jelenteni: mélyreható változások közepette éljük le életünket - a tét pedig maga a túlélés. Vajon sikerülni fog magunkévá tenni a megértést és a bölcsességet, és sikerül túlélnünk ezt az átalakulást? A következő oldalakon azon különös fontossággal bíró tennivalókat olvashatjuk, amelyek végrehajtása segítségével a fenti kérdésre pozitív választ tudunk majd adni.

\section{Nézz a múltba, hogy elöre láthass!}

Nem ez lesz az első alkalom a történelemben, hogy az emberiség globális szintủ változásokra ébredt. Holmes Rolston filozófus arra hívta fel a figyelmet, hogy „nagy történelmünk” során három ilyen nagy átalakulást, szó szerinti „Ösrobbanást” éltünk meg. ${ }^{1}$ Az első a mintegy 18,8 milliárd évvel ezelőttre tehető, fizikai értelemben vett Ösrobbanás volt. Ennek nyomán jött létre az univerzum a maga kvantumrészecskéivel, sokféle energiájával és galaxisok milliárdjaival. Ez vezetett a naprendszerek kialakulásához, napokkal és bolygókkal, valamint olyan energiaáramlásokkal, amelyek lehetővé teszik az élet evolúcióját az ún. lakhatósági zónán belül elhelyezkedő bolygókon, amelyek aktív nap körül keringenek.

A második alapvető átalakulás, avagy a „második Ösrobbanás" az élő organizmusok a Földön történő megjelenése volt. Ez az átalakulás körülbelül 3,8 milliárd évvel ezelőtt történhetett. Egysejtű prokarióták az akkoriban a bolygó felszínét borító őslevesben történő megjelenésével kezdődött.

A „harmadik Ösrobbanást” körülbelül 120.000 évvel ezelöttre teszik. Ez pedig alapjaiban változtatta meg - „fejlesztette ki” - fajunk tudatosságát. A Homo ekkor lett sapiens. A fejlett tudatosság evolúciós előnyei többek között azt is jelentik, hogy az ember a környezetéhez viszonyítva felismeri és azonosítja önmagát, és másokkal kommunikál. A felismerés nem korlátozódik le az itt és most állapotára, a kommunikáció pedig nem merül ki félautomatikus, ismétlődően megfigyelt feltételek

1 Holmes Rolston III. Three Big Bangs: Matter-Energy, Life, Mind. New York, Columbia University Press, 2010. által kiváltott válaszokban. A határ kitolódott az aktuális szituációt közvetító jelekre. Az emberi kommunikáció konszenzuson alapuló szimbólumok széles skáláját foglalja magába, amely nem csak a jelenre, hanem a múltra és a jövőre is vonatkozhat.

A szimbólumnyelv kifejlődése hatalmas ugrás volt. Egyrészt, kollektíven kifejlesztett jelentéseken alapuló társadalmi struktúrákat keltett életre, másrészt pedig manipulatív készségek széles skálájának engedett teret. Közösségek, társadalmak, egész kultúrák fejlődhettek ki az egyezményes jelentések nyomán, amelyek egyre erőteljesebb, közös tudáson alapuló technológiák megjelenését is lehetővé tették. A „Homo sapiens sapiens” a többi faj fölé emelkedhetett, és kulcstényező lett a bioszférában élö fajok evolúciója tekintetében.

A harmadik Ösrobbanás lehetővé tette az emberek számára a más fajokat korlátozó, határokra fittyet hányó szaporodást, ez pedig a populáció robbanásszerű növekedését eredményezte. Egyre több és több ember került a gépezetbe, ám ez nem járt együtt azzal a bölcsességgel, amely kiterjedt volna arra is, hogy a megnövekedett populáció fenntartaná a bolygón egy magasabb létformához szükséges ökológiai és energiaáramlási egyensúlyi állapotokat. Ezek az egyensúlyi állapotok egyre nagyobb terhelésnek és károsodásoknak vannak kitéve. Így került az emberiség oda, ahol ma tart: arra a kritikus pontra, amelyből vagy összeomlás, vagy áttörés lesz. Ez az ún. „káoszpont”. ${ }^{2}$

Újabb globális átalakulás vált elengedhetetlenné, amely már el is kezdődött: a negyedik Ösrobbanás. Ez pedig a Homo túlélését helyezi a középpontba. Ha bölcsen cselekszünk, felkészülünk rá. Így ésszerủ esélyt kapunk arra, hogy az emberi faj eltűnése helyett a Homo földi létének új fázisába lépjünk át.

Ideje okulnunk a múltból.

\section{A múlt leckéi}

Az első és alapvető lecke egyszerủ és evidens. Az elmúlt mintegy száz évben eltávolodtunk attól

2 László Ervin: Káoszpont: Válaszút elött a világ. Kossuth Kiadó Zrt., 2006. 
a világtól, amely ezen a bolygón fejlődött ki, és most vissza kell térnünk ehhez - nem vadakként vagy primitív lényekként, hanem olyan emberként, akik összhangban élnek azzal a világgal, amelyből életre hívattak. Szinkronban kell élnünk a bioszféra ritmusaival és egyensúlyaival. A saját magunk által teremtett ritmusoknak és egyensúlyoknak igazodniuk kell a körülöttünk lévő világban uralkodó ritmusokhoz és egyensúlyokhoz.

Már nem igazodunk a bioszféra ritmusaihoz és egyensúlyaihoz. Bár biológiai evolúciónk szerint ezen ritmusokba és egyensúlyokba „születtünk bele", mesterséges ritmusokat és veszélyes egyensúlyokat hoztunk létre, amelyek az előbbieket figyelmen kívül hagyják, gyakran velük ellentétesek. A Nappal való felkelés és lefekvés azt jelenti, hogy felvesszük a Föld a Nap [és saját tengelye] körüli mozgásával létrehozott huszonnégy órás ritmust. Az ún. primitív népek még mindig harmóniában élnek ezzel, csakúgy, mint a még fennmaradt bennszülött és tradicionális kultúrák. A modern emberek ezeket a ritmusokat és egyensúlyokat figyelmen kívül hagyják, és úgy hiszik, hogy azokat lámpák és egyéb mesterséges kényelmi eszközök fel- és lekapcsolásával egy mozdulattal helyettesíthetik. Azonban, az emberi test egy egész rendszer, amely a bioszférával együtt fejlődött évszázadokon és évezredeken keresztül, és még nem áll készen arra, hogy a mesterséges ritmusokat és egyensúlyokat felvegye. A következményeket pedig megszenvedjük. Az emberi immunrendszer hatékonysága csorbát szenved, és egyre több ember lesz fizikailag és mentálisan „természetellenes”. Annak ellenére, hogy közvetlen jólétünket egy sor mesterséges technológia hivatott elősegíteni, immunrendszerünk károsodik, így egyre több fertőzésnek és betegségnek esünk áldozatul.

A bolygó ökológiáját túlterheljük és kimerítjük. Felmelegítjük a levegőt, és korábban zöldellő területeket steril sivataggá változtatunk. Populációink gyorsabban növekednek, mint amilyen ütemben azokat fenn tudnánk tartani. Csökkentjük a bioszféra létünket fenntartó kapacitását, ugyanakkor egyre jobban terheljük ezt a kapacitást.

Ma az összlakosság 55 százaléka városlakó, és a Világbank adatai szerint, a városi emberek aránya 2050-re eléri a 68 százalékot. Ez azt jelenti, hogy az emberek kétharmada a természettel csak korlátozott kapcsolatot lehetővé tévő körülmények között él. Egyre többen élünk egy mesterséges világban, ahol a természetes világ egyensúlyainak és ritmusainak követése egyre több nehézségbe ütközik. A természet fenntarthatósági határainak átlépésére vonatkozó intő jeleket és jelzéseket figyelmen kívül hagyjuk, vagy ha ez nem lehetséges, azokat elvetjük.

Míg saját létünkre és jólétünkre koncentrálunk, figyelmen kívül hagyjuk azt a tényt, hogy a bolygón egy életközösségben élünk. Azt hisszük, hogy a többi fajt szolgálatunkba és igánkba hajthatjuk: a technológiáink erősebbé tesznek minket, mint amilyenek ők. Mostanáig még azt is tagadtuk, hogy más fajoknak hozzánk hasonló érzései és érzelmei lehetnek. Nem több, mint csupán ötven évvel ezelőtt, Jane Goodall, állatintelligencia kutató kénytelen volt megharcolni azzal az egészen addig honos meggyőződéssel, hogy a csimpánzok biológiai stimulusok által irányított mechanizmusok, és nem élő és érző lények. Ma már tudjuk, hogy nem csak a főemlősök, hanem minden élőlény, még a fák és növények is érzékeny élollények, és ebből a szempontból alapjaiban nem különböznek tőlünk.

Ma már olyan jeleket is tapasztalhatunk, amelyek feltételezéseink korrekciójára utalnak, valamint arra, hogy vissza kívánunk térni egy természetesebb életformához. Alternatív gyógy- és egészségmegőrzési módok terjednek el, köztük az információ- és energiagyógyászat is. ${ }^{3}$ A természetes gyógyítási technológiák és gyakorlatok reneszánszukat élik, különösen a Távol-Keleten. Ennek eklatáns példája a shinrin yoku, a japán erdőfürdő. Ennek gyakorlásához az szükséges, hogy kimenjünk az erdőbe, és felvegyük annak ritmusait és energiáit - halljuk, ahogyan a szél zörgeti a leveleket, lássuk a pocsolya felszínén játszadozó fényeket, ússzunk együtt az égen tovahaladó felhőkkel. A pszichoterapeuták szerint a természet hangjai, a madárcsicsergés és a patakok zubogása is gyógyít. Csupán az, hogy az erdőben vagyunk, vagy egy fa mellett állunk, nyugtatja az idegrendszert.

A természetre történő visszahangolódás egy nagyszabású, és teljes mértékig létfontosságú feladat. Ezen kívül vannak még más létfontosságú feladataink is; itt egy rövid lista következik az érdeklődők számára, bárhol is legyenek.

\section{A létfontosságú feladatok}

A következő feladatokkal történő azonosulás és azok gyakorlása úgy tünik, teljes mértékben létfontosságúvá vált.

3 Ervin Laszlo and Pier Mario Biava: Information Medicine. Healing Arts Press, Rochester, VT 2019. 
- Nagyon fontos, hogy az emberek újból megtalálják az összhangot a bolygó bioszférájával. Itt két különösen fontos tényezőt emelnénk ki: az emberi termékenység fenntartható szintjére történő visszaállást, és az emberi lét a biokémiai és termodinamikai egyensúlyra gyakorolt hatásának korlátozását. Ezen két feladat végrehajtása a lét magasabb formájának előfeltétele. A népesség növekedésének vissza kell térnie arra a mértékre, amelyet a bolygó még el tud tartani; az ember által erre a kapacitásra helyezett terhelésnek tiszteletben kell tartani annak határait. A már ismert társadalmi-gazdasági tényezők mellett (például egy olyan társadalmi és gazdasági biztonság megteremtése, amely szükségtelenné teszi a nagy családokat), mindkét tényező függvénye a szoros és érzékeny kapcsolatnak ember és természet között.

Ezen különösen fontos célokon túl, egy sor további, az emberi lét hatásaival összefüggő feladatot kell megoldanunk.

- Nagyon fontos, hogy olyan közösségi médiumokat hozzunk létre, amelyek az embereket összehozzák, hogy megosszák álmaikat és céljaikat, problémáikat és kudarcaikat. Ha az emberek több, személyestől a szakmaiig, a magántól a nyilvánosig, a helyitől a globálisig terjedő szinten is kapcsolódnak, az teret ad köztük az empátiának és együttérzésnek.

- Támogatnunk és erősítenünk kell az új, pozitív közösségépítő kezdeményezéseket, ha lehet, csatlakozzunk hozzájuk! Észrevehető eltolódás tapasztalható a hagyományos hierarchikus rendszerek és kapcsolatoktól a decentralizált élö- és munkakörnyezetek felé, amelyek inkább összekötik az embereket, mintsem eltávolítanák őket egymástól.

- Az informatikát az emberek közötti többszintű kapcsolatok serkentésére kell használnunk, az ellenőrző rendszerek helyett pedig nyitott, felhőalapú technológiákat kell alkalmazni. Az ilyen technológiák a korrupciót és az antiszociális vagy bűnelkövető magatartást felfedő, magasabb szintű átláthatóságuk révén csökkenthetik, és végül ki is küszöbölhetik a felülről történő irányítást.

- A feltörekvő technológiák, mint pl. a mesterséges intelligencia (AI), robotika, a dolgok internete (IoT) és a kvantumszámítógépek folyamatos orientációjára van szükség annak érdekében, hogy a hatalom és a gazdagság ne néhány szűk csoport kiváltsága legyen, hanem szét kell bomlasztani a jelenlegi hatalmi struktúrákat, és nyitni kell az innováció és kreativitás közkinccsé tétele felé.

- Az egészségügyi szektornak természettől független terápiákról és a szintetikus gyógyszerekről át kell tennie fókuszát a természetes gyógymódokra és a természeten alapuló gyakorlatokra. El kell ismerni a természetet, mint egészségünk és jólétünk forrása és erőforrása.

- Hasonlóképpen szükséges az oktatás rendszereinek átalakítása. A tanulási környezeteknek interkulturálissá és interaktívvá kell válniuk. A tanulókat és tanárokat össze kell gyüjteni a világ minden tájáról, ily módon egy olyan tanulási környezetet teremteni, ahol a tanulás nem egy elöre meghatározott pályán halad a tanár és a tanuló között. A klasszikus tantermeket nyitott környezetnek kell felváltania, ahol a tanulók elkészíthetnék, kifejleszthetnék a tananyagot ahelyett, hogy annak csupán fogyasztói lennének.

- A társadalmi státuszt ne az határozza meg, hogy az illető mennyi pénzt keres, és milyen luxuscikkekkel hivalkodik. Azt kell figyelembe venni, hogy az illető mire költi a pénzét, és amit megkeresett, azt hogyan használja fel.

- A városi, községi és nemzeti hatóságokat arra kell felszólítani, hogy csökkentség a megavárosokat és a zsúfolt városi csomópontokat olyan városi, elővárosi és vidéki közösségek és életterek létrehozásával, amelyek lehetővé teszik az embereknek, hogy megéljék az egymással, más közösségekkel és a természettel való kapcsolatot.

- Nemzeti, regionális és nemzetközi gazdasági intézményeket kell megszólítani annak érdekében, hogy a gazdasági szerveződés alternatív formáit hozzák létre, engedélyezzék és támogassák a disztributív számítási technológiák és a hálózati kommunikáció segítségével. A gazdasági tevékenységeket decentralizálni kell, elsődlegesen a mega-vállalatok által gyakorolt kontrollt kell 
áttenni a gyártók és fogyasztók bázisára. A fó célkitűzést a helyi környezetek, emberi és természeti erőforrások felfedezésében és fenntartható kiaknázásában kell meghatározni.

- A természet nem maradhat egy terhes externália a gazdasági előnyök kiszámításánál; egy, az emberi közösségeket és az élet alternatív formáit elfogadó, valamint az életet segítő környezetet biztosító gazdasági-pénzügyi rendszer szerves részévé kell, hogy váljon.

- Az átláthatatlan pénzügyi tranzakciók átláthatóvá kell, hogy váljanak, azokat kommunális intézmények, etikus bankok és hasonló, társadalmi előnyöket megcélzó szervezetek és eszközeik közötti tranzakcióknak kell felváltani.

- Meg kell kérdőjelezni azt az elképzelést, hogy a vállalatok kizárólag azért léteznek, hogy tulajdonosaiknak és részvényeseiknek pénzt hozzanak. Fel kell ismerni, hogy működésük elsődleges célkitűzése az emberek életének és jólétének, valamint az élet minden, a vállalatok tevékenységei által befolyásolt formájának, vagyis az érdekeltek szolgálata.

- Az üzleti vezetőknek és menedzsereknek minden tőlük telhetőt meg kell tenniük annak biztosítása érdekében, hogy a sikert és a vívmányokat ne kizárólag a piaci részesedés és a nyereségesség mentén mérjék, hanem a vállalat munkavállalói, együttműködői, ügyfelei és belső közösségei jólétéhez való hozzájárulása is játsszon benne szerepet.

- Az olyan politikusokat, akik elsődlegesen a saját szavazóbázisuk megtartásával és növelésével, valamint saját politikai túlélésükkel vannak elfoglalva, le kell váltani, és helyükre társadalmilag tudatos civil aktivistákat kell kinevezni. A hatalom megragadása és megtartása nem szabad, hogy a politika mindent maga alá rendelő célja maradjon.

- A közvéleményt a felületes patriotizmustól és a haderőn alapuló nemzeti büszkeségtől el kell irányítani egy olyan felismerés felé, hogy a pusztító képességekre alapozó katonai rendszerek és tömegpusztító fegyverek arzenáljai veszélyesek és egyben szükségtelenek. Az agresszió és erőszak motívumait a biztonság erőszakmentes eszközeivel lehet ellensúlyozni, biztosítani pedig szerény járőröző erőkkel, akik elég erősek ahhoz, hogy a potenciális agresszorokat és bűnözőket kontroll alatt tartsák, és szükség esetén a nemzeti és nemzetközi vészhelyzeti beavatkozó erők segítik ki őket.

Ezen és ezekkel kapcsolatos feladatok megvalósítsa utópisztikusnak tűnhet, ám lehetséges. Egy globális átalakulás küszöbén állunk, és ilyen átmeneti időkben megnyílnak a kapuk az alternatív, a túlélést és jólétet célzó viselkedési formák előtt is.

\section{Elöre tekintve}

A bioszféra több mint százmillió faj otthona, és minden faj egyedeinek milliói és milliárdjai élnek itt. Minden faj és egyed között is kiváltságos helyzetben vagyunk: agyunk és tudatunk magasan fejlett. Ennek segítségével feltehetjük a kérdést: kik vagyunk mi, miből áll a világ, és hogyan cselekedhetünk, hogyan kell cselekednünk a világban.

A magas szintű tudatosság egyedi erőforrás, de nem használjuk ki eléggé. Nem tesszük fel a megfelelő kérdéseket, és nem keressük a megfelelő válaszokat, csak menetelünk elöre a jószerencsében bízva. Számunk megnövekedett, de a tudatos agyunk által az utánunk jövő generációk számára potenciálisan kínált előnyök mértékét nem növeljük. Bonyolult technológiákat fejlesztettünk ki és alkalmaztunk szükségleteink és igényeink kiszolgálására, de károsítottuk vagy egyenesen kiöltük a legtöbb fejlett fajt. A bolygó vadon élő fajainak ötven százaléka eltűnt, és naponta negyvennégyezer élő organizmus-populáció tűnik el. Az élet csapásai lettünk a bioszférában.

Ideje, hogy átformáljuk gondolkodásunkat és módszereinket. A történelem azt tanítja, hogy a globális átalakulások, az Ősrobbanások nem feltétlenül hoznak virágzó létet; pusztításhoz és fajok kihalásához is vezethetnek. Elértük a negyedik Ösrobbanás küszöbét, és nem teszünk meg mindent annak érdekében, hogy elkerüljünk egy olyan pusztítást, amely kihalásunk előjeleként is értelmezhető. Az emberek többsége frusztrált és depressziós; egyre több emberben jelenik meg az agresszió. A társadalom kivetettjei által elkövetett erőszak világméretű jelenséggé vált, a nemzetközi migrációval egyetemben. Az emberek jelenleg a fenntarthatatlan demográfiai növekedés következményeit szenvedik, a negatív irányba változó klímát, és az ökológiai degenerálódást. 
A múlt leckéi előttünk hevernek, és nem veszünk róluk tudomást. Nem kellene így tennünk: tökéletesen képesek lennénk megélni ezen a bolygón anélkül, hogy tönkretennénk annak ökológiai és demográfiai egyensúlyát. Nem kellene egyetlen fajt sem megtizedelni, leigázni, vagy a kihalásba taszítani ahhoz, hogy életben maradjunk. Mégis, fajok sokaságát pusztítjuk ki, és károsítjuk közös környezetünket. Nem kell annál több embert a világra hoznunk, mint amennyit el tudunk tartani, és arra sincs szükség, hogy a szárnyasokat és az érzékeny emlősöket szaporodásra serkentsük kizárólag azért, hogy kényelmes (és hosszú távon egészségtelen) ételhez jussunk. Saját jogon fenntartható módon tudnánk élni, és más fajokkal is együtt tudnánk élni ezen a bolygón, egy fenntartható élet határain belül.

Miért nem teszünk meg mindent, ami ahhoz szükséges, hogy biztosítsuk életünk folytatását, és ezzel együtt minden élet folytatását a bolygónkon? Maga az a tény, hogy ötmillió évig sikerült fennmaradnunk, mint biológiai faj, és ötvenezer évig, mint tudatos faj, elég bizonyíték arra, hogy a probléma nem az alaptermészetünk. És valóban, nem az emberiség nagy része a felelös azért, hogy az élet csapásaivá váltunk a bioszférában, hanem csupán az emberiség egy kis szegmense. Ez a kis szegmens miért hozott létre egy fenntarthatatlan, mostanra kritikussá vált feltételeket az élet folytatásához?

Nem vagyunk sem ördögök, sem angyalok. Természetes faj vagyunk, akik beleszülettünk a bolygó önfenntartó élethálózatába, de populációnk egy szegmense elfelejtette, honnan jött, és ők maguk lettek a probléma.

A történelemből megtanultuk, hogy a csiszolt kőkorszak hajnalán az emberiség egy szegmense eltávolodott attól a kontrollrendszertől, amely az élő fajokat a fenntarthatóság keretein belül tartja. Erre már volt példa az élet krónikájában. Azonban, ha ilyen történik, a természetes szelekció kiszelektálja a határokat átlépő populációt. Az emberiség fenntarthatatlan módon élő szegmense nem szelektálódott ki, nem halt ki, ellenben egyre több, bonyolult technológiát fejlesztett ki a többi faj kárára azért, hogy életben maradjon. A Közel-Kelet részei, amelyek addig a Zöldellő Köz nevet viselték, az emberi civilizáció szülőhelyei voltak, és először száraz klímájú, később sivatagos hellyé változtak.

Az emberiség kalandvágyó szegmense nem zavartatta magát: más földeket és népeket gyarmatosított, tovább haladt Ázsiába és Európába. Továbbra is a bolygó erőforrásait használta saját erejének és kényelmének növelésére. Egy véges bolygón, ahol a fajok mind hálószerüen egymástól függenek, az ilyen énközpontú célok hajszolása felér egy öngyilkossággal. Ám az emberiség gazdagság- és hatalomközpontú szegmense nem tágított: nem reformálta meg gondolkodását, ehelyett egyre több kompenzációs technológiát fejlesztett ki az életben maradásért. Az alapvető élelmiszerek előállítása tekintetében a legeltetést felváltotta az állattenyésztés, majd a mezőgazdaság.

Az emberiség kalandvágyó szegmense elrugaszkodott azoktól a ritmusoktól és egyensúlyoktól, amelyek a populációkat ellenőrzés alatt tartják. Énközpontú szegmense által vezérelve, az emberiség igába hajtotta a világot. Felszabadította az atomenergiát, és arra használja, hogy saját hatalomvágyát és kényelmi igényeit kielégítse. Az elektronokat integrált áramkörökbe terelte, és ezeket olyan technológiák vezérlésére használja, amely kommunikáció- és információvágyát enyhíti. Oly módon használja az energiát, amely nem a valódi szükségleteit fedezi, csupán rövidtávú kényét-kedvét szolgálja. Az információt hasonlóan rövidlátó módon manipulálta. Egyrészről atombomba és az atomerőművek, másrészről pedig a számítógép a globális információáramlási hálózatával ennek kitűnő példái.

A nukleáris energia, még ha békés célokra használják is, a robotika, a mesterséges intelligencia és egyéb automatikus folyamatok, még ha jó szándék áll is mögöttük, technológiailag kicsúszhatnak irányításunk alól. Ahelyett, hogy szolgálnának minket, uralkodnak rajtunk, és károsítják a természetes ellenőrzési folyamatokat, amelyek más fajokat, köztünk minket is fenntartható keretek között hivatottak tartani.

Elérkeztünk a negyedik Ösrobbanás küszöbére. Óvatosan kell megfogalmaznunk, hogy mit akarunk, és hogyan kívánjuk elérni azt.

László Ervin professzor emeritus, az MTA külső tagja, a Budapest Klub elnöke 